\title{
Evaluation of Serum Level and Tissue Expression of Galectin-7 in Patients with Hypertrophic Scars
}

\author{
E.M.K.Sanad ${ }^{1}$, N.E.Sorour ${ }^{1}$, A.A.El fallah ${ }^{2}$ and A.M.Elberber ${ }^{1}$ \\ ${ }^{1}$ Dermatology and Andrology Dept, Faculty of Medicine, Benha Univ., Benha, Egypt \\ ${ }^{2}$ Clinical and Chemical Pathology Dept, Faculty of Medicine, Benha Univ., Benha, Egypt \\ E-Mail: amiramaged85@gmail.com
}

\begin{abstract}
Hypertrophic scars [HS] are benign fibrous growths characterized by excessive deposition of extracellular matrix at sites of prior dermal injury. Galectin- 7 is thought to play a role during wound healing, functioning as a regulator of keratinocyte proliferation and migration that is central in maintaining and restoring epidermal homeostasis. So decrease in tissue expression and serum levels of galectin-7 may play a role in the pathogenesis of hypertrophic scars. The aim of the work is to evaluate serum level and tissue expression of galectin-7 in patients with hypertrophic scars compared with control subjects.this was a case control study, This study included 20 patients, suffering from hypertrophic scars [Group A]. In addition, 20 apparently healthy individuals of matched age and sex were chosen as a control group [Group B]. Patients were selected from the outpatient clinic of Dermatology and Andrology department of Banha University Hospitals in the period from January 2019 to April 2019, Serum and tissue level of Galectin-7 were measured using Human Galectin-7 ELISA Kit supplied by Biokit Company, China. Serum level and tissue expression of galectin-7 were found to be lower in HS Patients than control and Serum level of galectin-7 positively correlates with its tissue expression level, No statistical significant correlations between galectin-7 tissue expression level and age, or duration of the lesion [P>0.05 for all]. we concluded that that HS is associated with decreased tissue and serum levels of galectin-7. These results suggest that the differences in galectin-7 expression may be crucially involved in the pathogenic process of HS.
\end{abstract}

Keywords: Galectin-7, Tissue, Dermatology, Hypertrophic, Scars.

\section{Introduction}

Cutaneous scarring is an inevitable consequence of normal wound healing; it restores the integrity of the integument after skin injury [1]. However, hypertrophic scars [HSs], which are attributed to an excessive healing response, lead to impaired functional mobility and compromised cosmetic outcomes. Normal wound healing process balances several requirements: prevention of infection, restoration of epithelial integrity and approximation of normal skin structure and function 2].

Hypertrophic scarring results from a disruption of this delicate balance. A prolonged inflammatory phase results in the persistence of myofibroblasts in the wound and elevated levels of fibrogenic cytokines, such as transforming growth factor [TGF] $\beta 1$ and connective tissue growth factor [CTGF] [3].

Galectins are soluble animal lectins which bind to surface glycoproteins, all of which display weak binding to $\beta$-galactoside [4]. Galectins are a family of 15 animal lectins with a unique carbohydrate recognition domain that binds to $\beta$-galactoside derivatives. They can have intracellular [cytoplasmic and/or nuclear] or extracellular functions, even without a signal sequence, which is essential for the classical secretory pathway [5].
Galectin-7 is a prototype galectin that appears in the epidermis, coinciding with epidermal stratification as a marker of keratinocyte differentiation[6].

The aim of this work was to evaluate serum level and tissue expression of galactin-7 in patients with hypertrophic scars compared with control subjects.

\section{Subjects and methods \\ 2.1Type of study}

This study included 20 patients, suffering from hypertrophic scars [Group A]. In addition, 20 apparently healthy individuals of matched age and sex were chosen as a control group [Group B]. Patients were selected from the outpatient clinic of Dermatology and Andrology department of Banha University Hospitals in the period from January 2019 to April 2019. Participants gave their informed consent before enrolment and the study was approved bythe Researsh Ethics Committee in Faculty of Meddicine, Banha University.

\subsection{All participants in this study were subjected to the following \\ All patients included in the study aged from 20- 40 years old. Both sexes were involved. Scars duration $\leq 6$ months. None of the patients was}


receiving treatment for $\mathrm{HS}$ before 3 months of the study or receiving systemic corticosteroids. Also Patients with facial hypertrophic scars or suffering from an undiagnosed inflammatory condition were excluded.

\subsection{Laboratory investigations}

This test was done using Human Galectin-7 ELISA Kit supplied by Biokit Company/China according to the manufacturer's instruction.

\subsection{Measurement of human galectin-7}

Blood samples were obtained and samples were allowed to clot, then serum was separated by centrifugation 20- min at the speed of 2000-3000 r.m.p. for $30 \mathrm{~min}$., the separated serum was aliquated and stored at $-20^{\circ} \mathrm{c}$ till assay. Four $\mathrm{mm}$. punch biopsy was taken from patients and controls and prepared to obtain supernatant which was removed for assessing tissue level of Galectin-7.

\subsection{Statistical Analysis}

The collected data were tabulated and analyzed using SPSS version 16 soft ware [Spss Inc, Chicago, ILL Company]. C.R. Khothari, Research Methodology: Methods and Techniques, New Age International, New Delhi, 2004.

\section{Results}

This study included 40 subjects, 20 patients with hypertrophic scars and 20 normal subjects as a control.

Mean serum level of galectin-7 was statistically significant lower in patients than controls Table (1).

Table (1) Comparison between the two studied groups according to serum level of galectin-7

\begin{tabular}{|c|c|c|c|c|c|c|c|c|}
\hline \multirow[t]{2}{*}{ Variable } & \multicolumn{3}{|c|}{ Patients [N=30] } & \multicolumn{3}{|c|}{ Controls $[\mathrm{N}=\mathbf{3 0}]$} & \multirow[t]{2}{*}{$\mathrm{Z}_{\text {MwU }}$ test } & \multirow[t]{2}{*}{$\mathbf{P}$} \\
\hline & Mean & $\pm \mathrm{SD}$ & Range & Mean & $\pm \mathrm{SD}$ & Range & & \\
\hline $\begin{array}{l}\text { Serum } \\
\text { galactin-7 } \\
{[\mathrm{ng} / \mathrm{ml}]}\end{array}$ & 2.07 & 0.62 & $\begin{array}{l}0.2- \\
4.64\end{array}$ & 8.65 & 3.4 & $\begin{array}{c}0.61- \\
14.1\end{array}$ & 3.05 & $<.05[\mathrm{~S}]$ \\
\hline
\end{tabular}

\section{Discussion}

Hypertrophic scars [HTS] are characterized by excessive deposition of collagen in the dermis and subcutaneous tissues secondary to traumatic or surgical injuries. They result from aberrations in the process of physiologic wound healing[7].

The aim of this study was to evaluate the possible role of galectin-7 in the pathogenesis of hypertrophic scars in patients by measuring its level in the serum and tissue of hypertrophic scar patients.

This study included 20 patients with hypertrophic scars and 20 individuals of matched age and sex were chosen as a control group. These subjects were chosen between ages 20-40 years old and confirmed diagnosis by dermatological examination.

Results of the current study showed that serum level and tissue expression of galectin-7 was statistically significant lower in hypertrophic scar patients than controls indicating that serum and tissue galectin-7 can be used in diagnosis of hypertrophic scars .

Galectin-7 is thought to play a role during wound healing functioning as a regulator of keratinocyte proliferation and migration that is central in maintaining and restoring epidermal homeostasis [6]. Furthermore, galectin-7 has been proposed a regulator of apoptosis, based on its proapoptotic effects noted in epidermal responses to a variety of stimuli [8].

\section{Conclusion}

Our data add novel aspects to the role of galectin-7 in the pathophysiology of hypertrophic scar patients. Also as the level of galectin-7 decreases, the chance of the disease is increased.

\section{References}

[1] T.N. Demidova Rice, M.R. Hamblin , I.M. Herman , Acute and impaired wound healing, pathophysiology and current methods for drug delivery, Adv Skin Wound Care, PP.25, 304314, 2012.

[2] D. Duscher, V.W. Wong, R.C. Rennert, M. Januszyk , M.Rodrigues, Mechanotransduction and fibrosis, J Biomech, Vol.47,PP.1997-2005, 2014.

[3] T.A. Wynn, Fibrotic disease and the TH1/TH2 paradigm, Nat Rev Immunol.,Vol.4(8), PP.583-94, 2004.

[4] R.D. Cummings, F.T. Liu, G.R. Vasts, Galectins Cold Spring Harbor LaboRATORY Press chapter Vol.36, PP.153-88,2017.

[5] K. Biron-Pain, A.A.Grosset, F. Poirier, L .Gaboury, Y. St-Pierre, Expression and functions of galectin-7 in human and murine 
melanomas, PLoS One., Vol.8(5), PP.633-07, 2013.

[6] G. Gendronneau, S.S. Sidhu, D. Delacour, T. Dang, C. Calonne, D. Houzelstein, Galectin-7 in the control of epidermal homeostasis after injury, Mol Biol Cell., Vol.19(12), PP.5541-9, 2008.
[7] B. Seo. S.N.Jung, The immunomodulatory effects of mesenchymal stem cells in pevention or treatment of excessive scars, Stem Cells Int.,vol43, PP.1-8, 2016.

[8] S. Saussez, R. Kiss , Galectin-7, Cell Mol Life Sci, Vol.63,PP.686-697, 2006. 